\title{
Environmental Managers and Institutional Work: Reconciling Tensions of Competing Institutional Logics
}

\author{
Frederik Dahlmann \\ University of Warwick \\ Johanne Grosvold \\ University of Bath
}

\begin{abstract}
Firms face a variety of institutional logics and one important question is how individuals within firms manage these logics. Environmental managers in particular face tensions in reconciling their firms' commercial fortunes with demands for greater environmental responsiveness. We explore how institutional work enables environmental managers to respond to competing institutional logics. Drawing on repeated interviews with 55 firms, we find that environmental managers face competition between a market-based logic and an emerging environmental logic. We show that some environmental managers embed the environmental logic alongside the market logic through variations of creation and disruption, thus over time creating institutional change, which can result in blended logics. Others, however, pursue a strategy of status quo or disengagement through maintenance or other forms of disruption, where the two logics coexist in principle but not in practice; instead the market logic retains its dominance. We discuss the implications of our findings for research.
\end{abstract}

KEY WORDS: environmental management, institutional work, institutional logics

\section{INTRODUCTION}

GIRMS ARE INCREASINGLY expected to minimize their impact on the natural Fenvironment in their pursuit of profit and growth (Schneider, 2015). Meeting the profit objectives of the firm, whilst simultaneously caring for the natural environment, can pose significant tensions for firms, since the added costs of ecologically responsible practices can detract from, rather than add to, the firm's bottom line (Hahn, Figge, Pinkse, \& Preuss, 2010). Research concerned with understanding how firms meet competing or incompatible demands for their time and resources has conceptualized such tensions with the help of institutional logics (Lounsbury, 2007; Marquis \& Lounsbury, 2007). An institutional logic is strongly value based (Lee \& Lounsbury, 2015) and provides the assumptions, rules, and beliefs, which shape field level decision making and actions (Dunn \& Jones, 2010; Marquis \& Lounsbury, 2007; Orlitzky, 2011). 
The field level in this context refers to the organizations that collectively "constitute a recognized area of institutional life" (DiMaggio \& Powell, 1983: 148).

Whilst extant research has focused on field level changes to institutional logics, a more recent phenomenon is the shift towards understanding how organizational and managerial actions help bridge competing institutional logics at the firm and the individual levels (Greenwood, Díaz, Li, \& Lorente, 2010; Lee \& Lounsbury, 2015; Reay \& Hinings, 2009). Whilst firms can face several logics at any one time, research typically emphasizes the dichotomous logics that may be pulling firms' attentions and objectives in competing directions, such as tensions between a trustee and a performance logic (Lounsbury, 2007), or a community logic versus a national logic (Marquis \& Lounsbury, 2007). Research on firms' engagement with the sustainability imperative often notes the significance of a logic that centers on the profit objective, and which can compete directly with decisions and actions designed to decrease the firm's impact on the natural environment and promote greener business models (Rousseau, Berrone, \& Walls, 2014). Despite the increased attention to firms' responsibility towards being better stewards of the natural environment, a surprisingly small body of research has studied those employees at firm level who are explicitly tasked with responding to environmental issues: the environmental manager. Instead, studies have focused on the long-term strategic environmental engagement and leadership at the executive senior management level of the firm (Arragon-Correa \& Sharma, 2003; Esty \& Winston, 2009; Sharma \& Vredenburg, 1998; Welford \& Gouldson, 1993), whilst leaving the day-to-day work, effort, and engagement of environmental managers relatively unexplored, and according to research, under theorized (Barley, 2008; Hine \& Preuss, 2008). Consequently, our understanding of environmental management is less developed at the lower organizational levels where much of the mundane work of environmental engagement occurs. More generally, researchers are increasingly calling for explorations of "how people engage in the doing of "real work" (Cook \& Brown, 1999: 387), specifically by focusing on the micro-level work and views of individual actors (Maguire, Hardy, \& Lawrence, 2004) and by using occupational domain oriented approaches to studying the effects of competing institutional logics (Greenwood et al., 2010; Jarzabkowski, Smets, Bednarek, Burke, \& Spee, 2013; Thornton \& Ocasio, 2008).

Theoretically, institutional work has been identified as a particularly useful lens through which to explore how tensions inherent in competing institutional logics are addressed over time (Deroy \& Clegg, 2015; Jarzabkowski et al., 2013; Reay \& Hinings, 2009; Smith \& Lewis, 2011; Zilber, 2011). Institutional work is defined as "purposive action of organizations and individuals aimed at creating, maintaining, and disrupting institutions" (Lawrence \& Suddaby, 2006: 215) and is concerned with how change happens through the agency of individuals who form part of, or are affected by, an institution (Lawrence \& Suddaby, 2006; Lawrence, Suddaby, \& Leca, 2011; Suddaby \& Viale, 2011).

In this study, therefore, we address the research question: How does institutional work help environmental managers respond to competing institutional logics? Drawing on repeated interviews with environmental managers in the UK, we investigate 
how institutional work changes over time as firms respond to the shifting centrality of competing logics. Our focus on environmental managers is motivated by their particular remit within firms, as these individuals often face the dual objectives of having to manage pressures emanating from a multitude of concerns about protecting the natural environment as well as continuing to respond to market-based pressures for growth and profit maximization (Fineman, 1997; Friedman, 1992; Lee \& Rhee, 2007; Rothenberg, 2007).

Our study makes two key contributions. First, we explore the effects of competing institutional logics on firms in the context of environmental management. In doing so, we empirically examine the existence and relative dominance of key institutional logics in this area characterized by tension and ambiguity. Our research therefore seeks to provide new insights into the extent to which key individuals within firms respond to pressures from dealing with environmental issues through their role-specific initiatives and practices. Secondly, we contribute to the theory of institutional work by painting a more nuanced picture of the different forms of creation, maintenance, and disruption individuals engage in. We find that individual actors shift their emphasis on different types of institutional work over time and that these variations can lead to very different organizational outcomes. Specifically, we show how once the imperative of a formerly peripheral logic is diffused more broadly across an organization, individual managers become better placed to manage competing tensions by embedding them within the structures and practices of the organization. As a result, environmental managers can rely on a wider range of institutional work forms and be more creative in their responses to the environmental and market-based logics (Almandoz, 2014; Hahn et al., 2010). Our study therefore responds to calls for improved dialogue between institutional logics and institutional work (Deroy \& Clegg, 2015; Zilber, 2011) by shifting the focus from field-level institutional change to explaining changes at the firm level, an area where there is currently little empirical research (Greenwood et al., 2010; Jarzabkowski et al., 2013; Lee \& Lounsbury, 2015).

Next, we develop our theoretical framing before detailing how our research was conducted. We then present our findings before discussing them in the context of our theoretical framing. Finally, a short section concludes.

\section{THEORETICAL BACKGROUND}

\section{Institutional Work and Competing Institutional Logics}

Existing theory suggests that field-level institutional pressures engender organizational change as firms and individuals seek to gain or maintain societal legitimacy by responding to and complying with the central institutional logics of their field (Bjerregaard \& Jonasson, 2014; Van Gestel \& Hillebrand, 2011). Scholars have sought to analyze how the simultaneous existence of multiple logics affects firms and individuals (Greenwood et al., 2010; Lee \& Lounsbury, 2015; Zilber, 2011). Extant research suggests that multiple logics concurrently compete for influence but that some become dominant or prevailing (Lounsbury, 2007; Reay \& Hinings, 2009; Thornton, 2002), and that over time competition can lead either to the emergence 
of new institutions, or the juxtaposition, blending, or hybridization of logics (Jarzabkowski et al., 2013; Reay \& Hinings, 2009; Rojas, 2010). This process of change can be challenging for those tasked with shaping the firm's response to competing logic, and is likely to be fraught with organizational and political tensions as well as the potential for organizational instability (Pache \& Santos, 2010; Yu, 2013).

It is in light of these potential challenges that the concept of institutional work can help explain individual managerial actions (Greenwood et al., 2010; Reay \& Hinings, 2009). Specifically, individuals engaged in institutional work are either concerned with "consciously and strategically reshaping social situations" (Lawrence et al., 2011: 53), or "focused on managing the exigencies of immediate situations" (Lawrence et al., 2011: 53) with a view to facilitate institutional change, and to bridge or blend competing institutional logics (Lawrence et al., 2011; Rojas, 2010; Smith \& Lewis, 2011). Unlike institutional entrepreneurship, institutional work is also concerned with understanding what happens in circumstances when change occurs that is not for the better (Lawrence et al., 2011) - a prospect that is very real when addressing competing logics that may have incompatible objectives and where unintended consequences and outcomes are not uncommon (Cruz, Delgado, Leca, \& Gond, 2015; Smith \& Lewis, 2011). Institutional work therefore moves the focus from changes at the field level to the managerial level and thus highlights the on-going efforts of social actors, who are embedded in the firm and who seek to reconcile competing tensions on a daily basis (Bjerregaard \& Jonasson, 2014; Lawrence et al., 2011; Reay \& Hinings, 2009).

Institutional work also allows for the reintroduction of a central role of creativity and action by individual managers, as it begins to address the conceptual paradox in institutional theory of how institutions are created, transformed, and changed, when institutional theory has historically rested on the premise that human agency is embedded in institutions that are deemed to control and limit human behavior and actions (Berger \& Luckmann, 1967; Thornton \& Ocasio, 2008; Willmott, 2011). Institutional work, therefore, is more concerned with the practices and processes explaining "why" and "how" rather than the outcomes of "what" and "when" (Lawrence et al., 2011), which has led to increasing interest in the interaction between institutional logics and work (Deroy \& Clegg, 2015; Gawer \& Phillips, 2013). Moreover, by focusing on how individuals in organizations manage institutional complexity, there is an argument that more practice-oriented research will provide the vital insights necessary for understanding how organizations cope with coexisting, contradictory logics (Jarzabkowski et al., 2013). Institutional work therefore offers a conceptual lens into such approaches, by studying how actors instantiate (create), reproduce (maintain), and modify (disrupt) practices at the firm level (Jarzabkowski et al., 2013; Lawrence et al., 2011; Lawrence \& Suddaby, 2006). Next, we explore how this might apply to our specific context of environmental managers.

\section{Environmental Managers Facing Competing Tensions}

Whilst research at the explicit juncture of institutional work, institutional logics, and environmental management is in its infancy, some existing findings on the role of environmental managers speak to the core tenets of institutional work by highlighting 
tensions between competing demands from shareholders and stakeholders (Bansal, 2003; Egri \& Herman, 2000; Fineman, 1997; Prasad \& Elmes, 2005; Sharma, 2000), which could be conceptualized as mirroring institutional logics. For example, pressures on environmental mangers to prioritize financial growth and minimize operational disruption (Bansal, 2003; Egri \& Herman, 2000; Prasad \& Elmes, 2005; Sharma, 2000) often mainly result in legislative compliance (Buysse \& Verbeke, 2003; Cordano \& Frieze, 2000; Sharma, 2000) and formalized processes (Klassen \& Whybark, 1999; Ramus \& Steger, 2000), rather than substantive change. This view of environmental management has been attributed to environmental managers' reluctance to see beyond "a philosophy of convenience that emphasizes minimum socio-economic disruption and maximum conflict avoidance" (Prasad \& Elmes, 2005: 863, emphasis in the original). By focusing our research on environmental managers and exploring to what extent their practices become institutionalized, we seek to shed further light on how environmental managers bridge the inherent tensions between profit maximization and ecologically responsible business practices through different forms of institutional work.

\section{METHOD}

\section{Research Setting and Sample}

We conducted repeated interviews with environmental managers from UK firms in 2006 and 2008. We chose to interview environmental managers as we sought to elicit their own experiences, efforts, and insights, in order to analyze the connection between managers' daily work and the parameters within which this took place (Lawrence et al., 2011). Data based on interviews is commonly used in research on institutional work (Currie, Lockett, Firm, Finn, Martin, \& Waring, 2012; Smets \& Jarzabkowski, 2013; Zietsma \& Lawrence, 2010) and institutional logics (Reay \& Hinings, 2009; Greenwood \& Suddaby, 2006), and offers particular benefits when the research is concerned with understanding individuals' work and continuing activities (Reay \& Hinings, 2009). Interviews allowed us to draw on respondents' recall of their subjective interpretations, justifications, and explanations (Reay \& Hinings, 2009) and therefore to gain an insider perspective into the institutional work conducted by environmental managers (Slager, Gond, \& Moon, 2012; Zietsma \& Lawrence, 2010).

The research design for this study was based on sampling firms across a range of firm sizes and economic sectors exposed to different environmental issues. We focused on six sectorial groups: food/drink, electronics, engineering, retailing, transport, and chemicals. These industries are exposed to many of the most pressing environmental challenges and provide a mix of service and manufacturing activities. We approached companies by mass-email or cold calling. 55 companies agreed to participate in two rounds of interviews, resulting in a total of 110 interviews. As our research sought to explore the views of those individuals most likely to be affected by issues related to environmental issues at the firm level, we asked companies to identify respondents who they believed to be the most appropriate contacts (Bansal \& Roth, 2000). As a result, respondents' roles were predominantly based in operational, but also commercial, executive, and other support functions (see Appendix). To a degree, the functional 
and hierarchical allocation of responsibility for the firm's environmental agenda was a reflection of the importance placed on environmental management by the firm. Beyond functional affiliation, their titles and organizational place also gave insights into the priority and powers afforded them by the firm. We refer to our interviewees as environmental managers throughout the article, irrespective of their actual job titles.

The first round of research took place between January and March 2006, the second round was conducted in December 2008, to obtain repeated insights into environmental practices (Sharma \& Vredenburg, 1998). Given our interest in the changing role of institutional work, this was an important methodological consideration designed to explore environmental managers' continuing efforts in terms of their organizational function and day-to-day practices. Table 1 provides a geographic, industry, and financial breakdown of our sample companies.

\section{Data Collection}

We collected data using phone interviews. On average, interviews in 2006 took 35 minutes, whilst in 2008 the interviews lasted, on average, 19 minutes, as they coincided with year-end commercial pressures. Interviews were transcribed verbatim and the resulting 147 pages of single-spaced transcripts analyzed by both authors. The interview questions were open-ended to permit respondents to choose freely how to answer, to encourage continued discussion, and to provide a richer source of information compared to closed-ended questions (Patten, 2002). Respondents were asked to illustrate their comments with examples drawn from recent experience (Sharma, Pablo, \& Vredenburg, 1999). Questions were neutrally worded to avoid terminology that might influence responses wherever possible. We addressed our interviewees with 'you' in order to encourage them to reflect on and talk about their own personal experiences and actions taken. To facilitate comparison across respondents, we adopted a structured interview approach where each respondent was asked the same open-ended questions. Standardized questions were developed and first piloted in five companies to check for issues of timing and question clarity. The survey structure was identical in both waves apart from two new open-ended questions, which were added in 2008 to probe more deeply into the effects of the economic climate. ${ }^{1}$

Table 1: Geographic, Industry and Financial Breakdown of Sample Firms

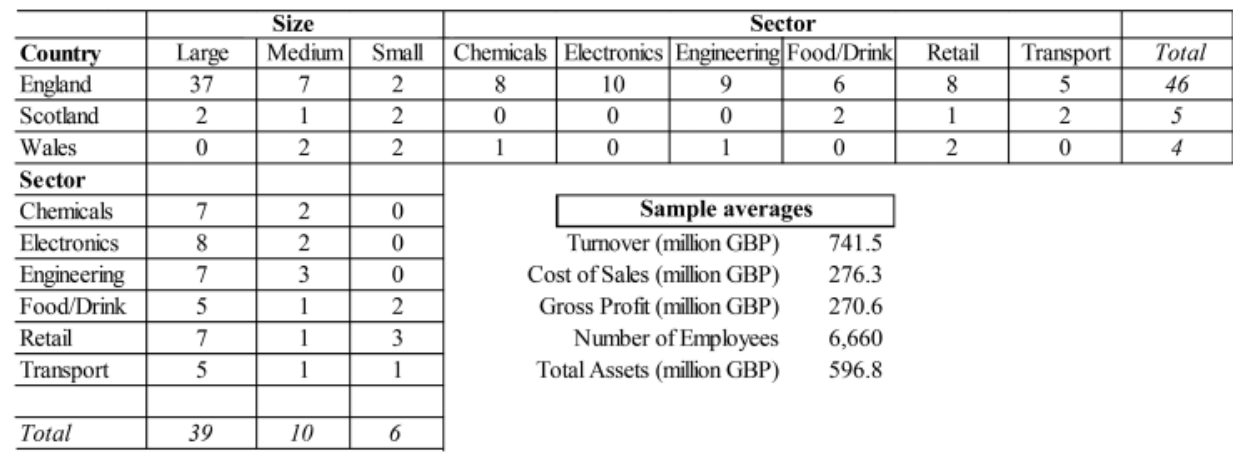




\section{Data Analysis}

In line with previous research into institutional work (Ramirez, 2013; Styhre, 2014) we employed an abductive research approach. Abductive analysis is driven by a focus on engaging with problems in the real world (Van Maanen, Sørensen, \& Mitchell, 2007). The abductive approach draws on empirical observations andby building upon existing theory-seeks to infer suitable or best explanations of such phenomena (Mantere \& Ketokivi, 2013). Alternative research approaches, such as pure deductive theory testing or inductive generalization, were also considered but deemed inappropriate given our desire to explore and explain managerial accounts of the efforts involved in navigating competing tensions (Lockett, Wright, \& Wild, 2015). In other words, our research was motivated by an interest in individuals' approach to managing the tensions and challenges inherent in their role, through institutional work. As such, the abductive approach involves constant iteration between empirical data and literature with the aim of matching theory and data and thus, the creation of first explanations of our findings (Roulet, 2015). These explanations then, grounded in existing literature, have the potential to shape the process of generalization and provide the building blocks for future theory development on institutional work (Mantere \& Ketokivi, 2013).

\section{Identifying Institutional Logics}

How to empirically identify institutional logics has been a topic of recent debate (Asangansi, 2012; Jarzabkowski, Matthiesen, \& Van de Ven, 2009). Reay and Jones (2015) found three ways to empirically identify institutional logics using qualitative data: pattern deducing, pattern matching, and pattern inducing. In our study we relied on pattern inducing interpretivist analysis. This approach adopts a grounded analytical method and takes as its starting premise the raw data, and from there, the researchers commute between extant literature and their coding of groups of themes that emerge from the data. These themes should reflect behaviour, norms, and beliefs observed in the data that are consistent with that of logic. Common data sources include interview data and personal reflections of the interviewee (Reay \& Jones, 2015). Such an approach starts with a broad question about the nature of the logics in particular research contexts, and thus allows for patterns aligned with logics to grow inductively from the data, which in turn can be compared with findings from existing studies. As our concern was with the situated lived experience of the environmental manager, this approach permitted us to understand the logics facing the environmental managers from an inside-out perspective (Myers, 2013). Pattern induction relies on capturing logics "by showing as much of the raw data as they can" (Reay and Jones, 2015: 9), such as text directly copied from interview transcripts.

In adopting this approach, we started with the broad question of how institutional work might help environmental managers respond to institutional logics. At this point we did not know what the exact nature of the logics would be, and while prior research had identified the pervasiveness of institutional logics across organizations 
(Greenwood et al., 2010; Lounsbury, 2002; Pache \& Santos, 2010), little had been done to connect the individual level engagement with logics and the doing of institutional work (Jarzabkowski et al., 2013). We began our analysis by immersing ourselves in the data while reflecting on our understanding of existing logics literature. Both authors reviewed and identified from the data the observed patterns of norms, attitudes, beliefs, and experiences commensurate with the characteristics of an institutional logic (Dunn \& Jones, 2010; Greenwood et al., 2010; Lee \& Lounsbury, 2015; Thornton \& Ocasio, 1999). We followed the approach now known as the Gioia method (Corley \& Gioia, 2004), which relies on axial, first, and second order coding before abstracting overarching themes. Both authors clustered findings into groups believed to be meaningful themes of behavior, which resulted in broadly similar categories at the axial level. Before progressing to the first order coding stage, we compared categories and discussed differences in coding. In most instances, differences were in fact due to the use of different language to describe qualitatively similar constructs. The same approach was adopted at the first and second order level. When there was uncertainty or disagreement, we referred to the source data and sought agreement after further deliberation. At the abstract theme level, we agreed that two overarching logics emerged from the data. Some quotes identified at early stages of abstraction were subsequently found not to fall into any distinct pattern or discernible category and therefore were discarded. Grouping our themes and findings allowed us to align them with the patterns and behaviors of the two logics we eventually identified, the market logic and the environmental logic. Consistent with pattern inducing interpretivist analytical method, we relied on a combination of raw data tables and a Corley and Gioia (2004) style diagram to show our logic development. Additionally, we were able to further strengthen the credentials of our logic identification by showing changes to the logics over time, which Reay and Jones argue "explain the distinguishing feature of pattern inducing — which is the identification or capturing of logics based on ground-level data and a process of upward theory building" (2015: 10).

Whilst we are confident in the robustness of our method, there are ways in which the research could be enhanced in the future. First, our research was based on respondents volunteering to discuss their engagement with environmental issues. Thus, while a certain degree of self-selection bias from individuals keen to highlight their firms' positive responses is inevitable, we also noted others wanting to lament their organizations' poor track record. In that sense, many responses may appear to be extreme cases. Different sampling strategies may uncover insights from more "average" type firms. Likewise, our research was conducted across different firm sizes and industries. We did not, however, seek to examine the relevance of industry or firm size differences, which could deliver additional perspectives into the role of institutional work in managing competing institutional logics in particular contexts. The data to emerge from our interviews provided a rich source of material for our research question. We do, however, recognize that our research neither contains any observational data collected in situ, nor any archival data. Further research drawing on these different types of data sources can help triangulate our findings. Consistent with the view that any 
context is potentially influenced by competing logics of different societal sectors (Scott, 2000; Thornton \& Ocasio, 2008), we also cannot rule out the existence of other logics affecting our target firms, but which we did not identify with our research strategy. For the purposes of our article, however, we are satisfied that we have captured the most significant logics affecting environmental managers and their work.

\section{FINDINGS}

\section{Institutional Logics in 2006}

The initial step in our research sought to establish the existence and relative salience of the different logics facing environmental managers and the firm. One of our first questions was, therefore, what environmental managers thought to be the most keenly felt institutional pressures. This enabled us to assert whether there were any competing institutional logics, which could be negotiated through institutional work, and provided a clearer picture of the backdrop against which we would be exploring their work and engagement. Figure 1 shows the structured coding of institutional logics faced by our firms in 2006 and 2008.

We identified two institutional logics, an environmentally driven logic, and a market based logic. The market based logic centered on legitimacy and profit maximization, whilst the environmental logic was concerned with protecting the natural environment and decreasing the firm's impact on natural resources. Both logics formed part of environmental managers' work and their view of their role in both 2006 and 2008; however, over time the environmental logic took on a broader remit and a more central role in 2008 relative to 2006. Table 2 summarizes our analysis and provides illustrative data supporting the existence of key institutional logics identified in our two rounds of interviews.

Figure 1: Structured Coding of Institutional Logics

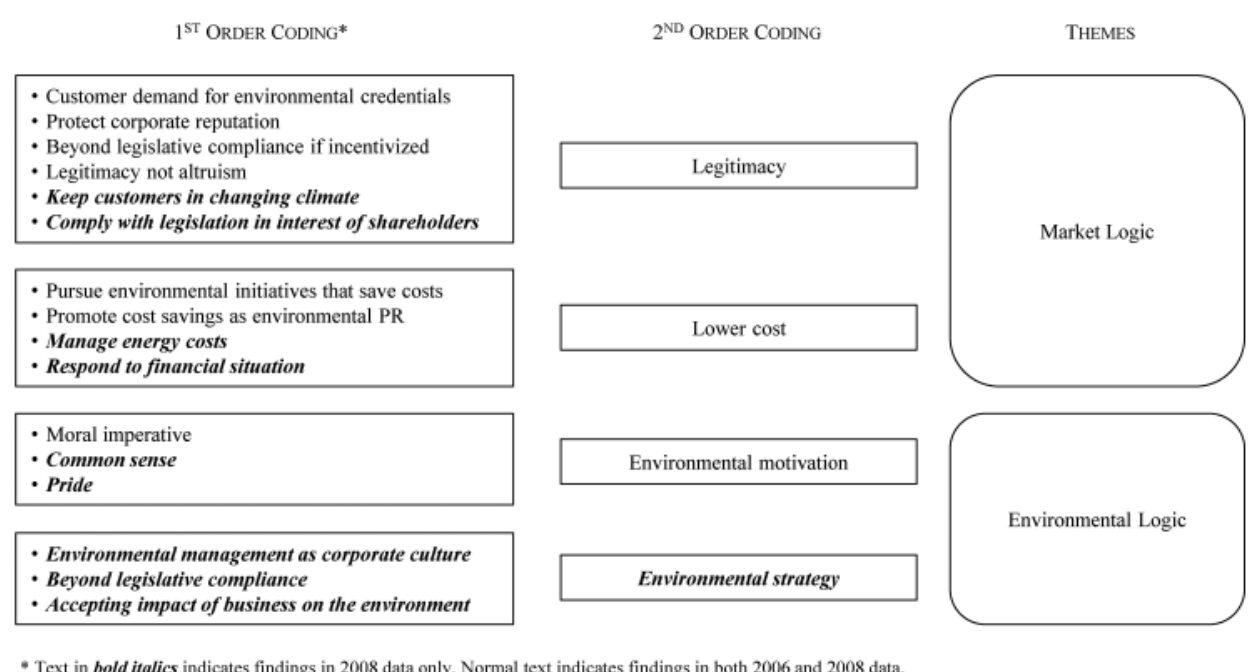


Table 2: Illustrative data supporting the existence of key institutional logics identified in 2006 and 2008

\section{Market logic}

\section{Legitimacy}

- Compliance with legislation \& regulation - Maintaining social licence to practice

- Safeguarding corporate reputation

- Avoiding penalties \& fines

- Responding to environmental taxation

- Satisfying specific customer demands

\section{Lower Cost}

- Cost savings

- Waste reductions

- Operational efficiencies

- Organizational improvement
"Corporate reputation is important, we're a big multinational company...And stakeholders of all types, including the people who work here see that it's good business to have a good environmental image and a good reputation. We've got a reputation to live up to and keep going, and it saves money."

"We're not doing this for altruistic purposes."

"The key things are managing our legislative compliance at the local level, that is ensuring that we have our license to operate and then effectively responding to the views of external stakeholders. Whether it is people like shareholders, the socially responsible investor groups like Dow Jones sustainability and business unity. A lot of that is in terms of driver is really about managing our corporate reputation.'

"We've gone as high as ISO14,000 just to impress our customers."

"The cost of waste management is the biggest challenge to our business. Everything that doesn't go to the customer is money down the drain. The key driver is waste reduction with a view to enhance the business. More efficient waste reduction equals more money."

"We are a relatively small company but the main reasons for managing the environmental side is cost effectiveness. And if you reduce energy consumption, you reduce your costs. So one runs on from the other."

"Obviously the financial pressure in terms of if we can improve our efficiencies; fuel efficiencies and energy efficiency so we'll become a more efficient business." 
Table 2: continued

\section{Environmental logic}

\section{Environmental Motivation}

- Moral imperative

- Ethical duty

- Common sense

- Personal and corporate pride

- Part of organizational culture

\section{Environmental strategy}

- Proactively integrating environmental issues strategic and operational decision making
"It is not really a pressure for us but it is kind of ethical. It is the right thing to do. I know there are legal requirements out there as well but we are trying to go beyond compliance, and compliance is obviously legislation requirement and we try and go beyond that wherever we can so it is more an ethical thing for us."

"I think my first one is a moral obligation because obviously I am thinking about environment all the time because I've got young children who will have grandchildren and all that sort of stuff... So, the moral aspect is very high."

“... .because [our company] is part of the 'FTSE4Good' and the Dow Jones Sustainability Index and ...we take quite a lot of pride from being on these."

"Obviously, from our company's involvement, our standing is that we need to be seen to be doing a lot of things. Actually, it makes common sense to do the right things and most of the time, it is financially beneficial to the markets and also we should challenge the norm and look for innovation."

"The main driving force now within the company is actually coming out of corporate headquarters in Germany. They have never really pushed environmental management systems significantly hard in the past. They are now pushing it very hard, as part of their overall corporate responsibility strategies."

"[Environmental management] is part of our DNA as a company now." 
In 2006, environmental managers spoke of beliefs, values, and norms that related to the reputational cost of failure to comply with, for example, laws and regulations as part of the market logic. Satisfying customer demands for environmental credentials such as ISO14001 were suggestive of obtaining a baseline of environmental legitimacy, which was deemed crucial to maintaining the firm's reputation, which in turn was important to remain competitive. Having the right credentials was a central pressure for environmental managers, and not having them could result in a loss of legitimacy in the eyes of the customer. Legitimacy was thus a key driver in relation to environmental managers' daily responsibilities, and this was something that could best be achieved through regulatory and fiscal compliance. The emphasis of environmental managers' work was therefore broadly anchored in the market logic, with a marginal overlap with the environmental logic, in as much as the environment was an indirect beneficiary of customers' demands.

Lowering costs and improved efficiency was another pressure faced by our interviewees, who explained that the need to improve business efficiencies had resulted in the reduction of energy usage and consequently savings for the firm. The need for emissions reductions and the emphasis on business efficiency were, however, seldom coached in terms suggestive of direct responses to institutional pressures for more environmentally responsible business practices. Instead, they sought to address increased competition and rising costs. Any activity, initiative, or behavior that did not result in tangible efficiency gains or improved profits was, according to the environmental managers, not a priority, therefore implicitly casting doubt on the degree to which environmental managers' work was a desire to blend the two logics, rather than use the environmental logic as a justification for a market based response to lower costs and increased competitiveness.

By comparison, environmental managers who personally identified with the environmental logic voiced a narrative, which reflected pressures primarily felt from the need to protect the natural environment, or otherwise behave as responsible businesses. Those who framed the key pressures as being ecologically driven expressed a sense of moral duty and responsibility, rather than specifically noting that the natural environment would benefit as a result of their engagement. This was in contrast to those who aligned themselves more strongly with the market logic, but who articulated clear business benefits from doing so.

Collectively, our interviewees' responses made it clear that they were facing competing institutional logics, one focused on environmental protection and environmentally responsible business practices, whilst another much stronger force emphasized the need for commercial and customer legitimacy and cost efficiencies. The sense of market based pressures was felt much more keenly by our interviewees than those emanating from the environment, but environmental concerns was still very much a theme, albeit an emerging one. Therefore, the emerging environmental logic was beginning to encroach on the established and dominant market based logic and as such, challenged particularly environmental managers' practices, and their underlying pre-existing norms and beliefs about how to run a business. 


\section{Institutional Logics in 2008}

When we spoke to our interviewees again in 2008, we explored if and whether the institutional environment had changed since 2006. Broadly, we found evidence of a change in environmental managers' engagement with the environmental logic, which for many respondents had become more central. Whilst in 2006 isolated environmental managers acknowledged a moral imperative to act because of personal beliefs and attitudes towards protecting the environment, by 2008 such views were more common and often complemented by concepts such as "common sense," "culture," and "pride." These findings suggested that some environmental managers were becoming carriers of the values reflected in the environmental logic, which was emerging as a more central logic (Besharov \& Smith, 2014). For example, one commented: "I think generally I have become more of an advocate of environmental management and environmental issues than almost three years ago" (environmental manager, engineering). The literature on individuals as carriers of institutional logics suggests that the strategy a firm pursues may in part be determined by how the competing logics in question are reflected at the individual level, and how managers as individuals are cognitively motivated to address the competing logics (Fiss \& Zajac, 2004; Pache \& Santos, 2010; Tilcsik, 2010). Over time, such a shift has the potential to change into group norms, which in turn "become the immediate context for future thought and action" (Almandoz, 2014: 444). The change from 2006 to 2008 in environmental managers' experience of the centrality of the environmental logic was therefore indicative of a shift in the perception of their role, and their ability to shape their firms' engagement with competing logics.

For other environmental managers little had changed with regard to logic centrality since we spoke to them in 2006. Legitimacy and legislative compliance were still key pressures and the cost imperative took on a new level of salience beyond simplistic efficiency arguments and good PR: The sky-rocketing energy prices and operational stress factors caused by the financial situation many firms faced as the financial crisis began to unfold, suddenly elevated any activity that was deemed to be improving the firm's cost basis as an important contribution to business management from a market logics perspective.

\section{Institutional Work and Competing Logics in 2006}

Given our aim to contribute to the reconnection between the work and daily engagement of environmental managers and the "institutions that structure and are structured" (Lawrence, Malhotra, \& Norris, 2012: 52) by the individuals' work, we asked environmental mangers to tell us about concrete environmental initiatives they were working on. From this, we gained a sense of how environmental managers managed competing logics, and how their day-to-day work was operationalized. From our analysis we identified examples of all three key categories of institutional work: creation, maintenance, and disruption (Lawrence \& Suddaby, 2006). Figure 2 shows the data structure behind our analysis, and Table 3 provides illustrative quotes in support of our findings on the different types of institutional work. 
Figure 2: Data Structure of Institutional Work Based on Authors' Analyses

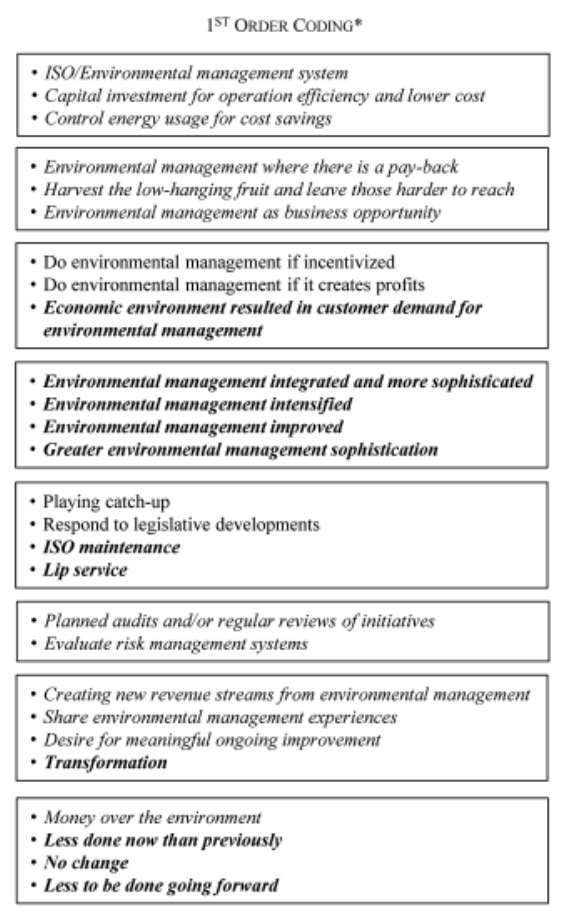

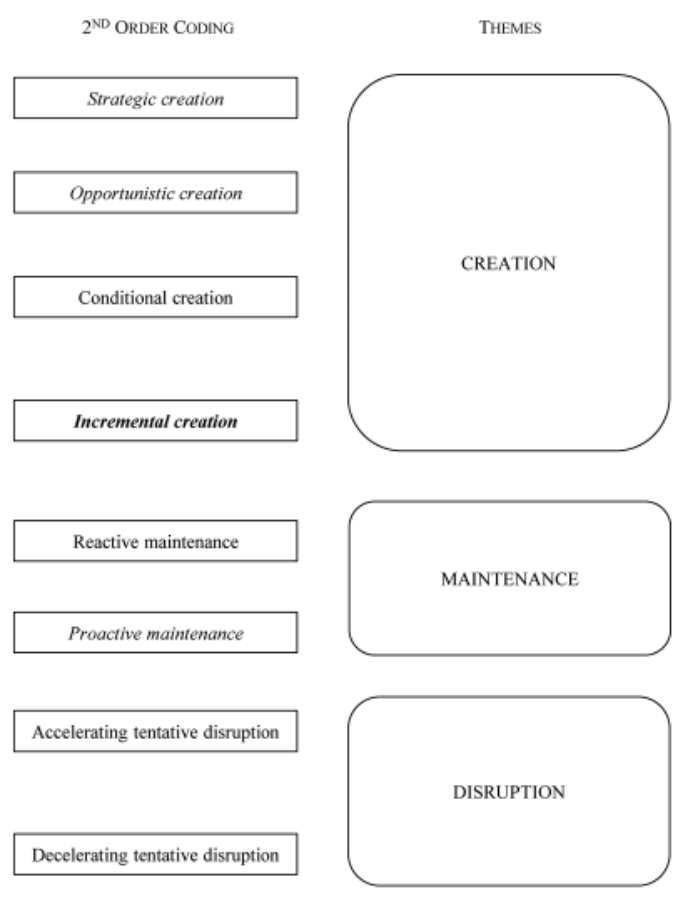

- Text in italics indicates findings in 2006 data only. Text in bold italics indicates findings in 2008 data only. Normal text indicates findings in both 2006 and 2008 data.

Creation. A key theme in our data was the institutional work form of creation, which is concerned with how new institutions or "templates for actions" (Lawrence et al., 2011: 53) emerge and how they become embedded (Jarzabkowski et al., 2009). We found three different variations of creation, which we labeled strategic creation, opportunistic creation, and conditional creation.

Strategic creation focused on environmental initiatives designed to incorporate environmental management into day-to-day strategy, through broad reaching environmental management systems and the introduction of technology that would diminish the firm's impact on the environment or otherwise change organizational behavior in ways that resulted in lower costs and environmental impact in the long run. As such, strategic creation not only served the environmental logic, but also supported the firm's response to the market logic, and thus contributed to a blending of the two logics. Those who engaged in strategic creation saw the opportunity to address the environmental logic within the parameters of broader strategic practices. Strategic creation helped environmental managers manage competing logics by utilizing structures and technologies that allowed for sustainable practices to be embedded alongside the firm's commercial objectives, without compromising business performance as it related to the market logic.

The second group we labeled as opportunistic creation. These managers framed their narratives by either identifying economically beneficial initiatives, 


\section{Table 3: Illustrative Data Supporting the Existence of Institutional Work in 2006}

\section{Strategic creation}

"We are trying to reduce energy consumption, and production of waste though our ISO certification."

"We're putting in renewable energy systems, solar panels, solar heat panels and transverse heating, waste energy recovery..."

"It might increase the financial costs in some cases but, in the longer term, investment in renewable technology or investment in low energy light fittings, will have some longer term financial benefits."

\section{Opportunistic creation}

"Anything which is environmentally beneficial, which will give us a payback as well, that needs to be investigated."

"I've just been enquiring about costs of recycling bins and I've had some figures back from a local paper waste collection service."

"We actively encourage our staff to bring plastic bottles in from home and tin cans for recycling... anything we find that we can recycle to minimize what goes into landfill, we will try and do."

"One of the big ones that's going on at the moment, because of the rising land fill costs, we are well on the way to rolling out a recycling initiative across all the manufacturing sites, to recycle cardboard, plastic and tin."

\section{Conditional creation}

"We've tried desperately to recycle a lot of packaging but we are hitting a brick wall with officialdom in local government. They appear to want to increase recycling from the private individual but not as far as companies are concerned, as we have to pay."

"We don't need any more advice or information; we just need to be able to make more money to be able to allocate a larger portion towards the actual initiatives."

"I know what we need to do. My problem is getting the commitment from some people and what to do, how do it and what to do."

\section{Proactive maintenance}

"We have an environmental policy at group level and the plan and our impacts are audited annually. Site-specific risk assessments also occur where they have environmental management assistance and or other legislative or environmental pressures."

"We have a risk management programme and so senior managers meet once every 6 months to brainstorm what they believe are emerging trends, emerging issues and then there is a scoring process which collates up the likelihood of that happening and then the severity to the business if that happens."

“Yes, I'm working with the Business Risk Management and we're looking at environmental issues there and we also have special environmental managers that are looking ahead and looking at the impacts of new legislation." 
Table 3: continued

\section{Reactive maintenance}

"I've complied with all the pollution regulations but we didn't want to go too heavy into it because we are moving to new premises where, and at the new premises we'll have to comply with whatever the current legislation will be at the time."

"Obviously there's new legislation coming out throughout the year."

"Well, actually packaging minimisation is a legal obligation for anyone who's shipping goods, you're obliged to do that anyway...but because packaging regulations applies levies to all your packaging and it's done on a weight basis, it's actually quite sensible to get the weight of the packaging down."

\section{Tentative accelerating disruption}

"I mean certainly we've reduced waste to landfill by 5 tonne a month. We're actually now earning revenue from our cardboard where we used to pay to get rid of our cardboard."

"One of the things that we were thinking of which was quite innovative was to actually try - and in these towns that we were in, because we might be a little bit ahead of the game - to use our branches to provide local advice or even some kind of recycling centre."

"Last year I've put in a building heating management system across the three factories that are on this site and we had our first four monthly report from the company that installed it...Suggesting to us that they had saved us about $£ 62,000 \ldots$.

\section{Tentative decelerating disruption}

"Not really [have any plans for environmental management], our main concern these days is keeping afloat." 
or they focused on the introduction of comparatively minor investments, such as the use of energy efficient light bulbs. There was similarly an increased focus on capitalizing on the here-and-now and the pursuit of opportunities that would provide a payback. Like the environmental managers who pursued a more strategic alignment of environmental initiatives, the environmental managers engaged in opportunistic creation also sought to address the environmental logic by creating opportunities for more environmentally friendly behavior. Yet they did so independent of major strategic initiatives, and instead, introduced comparatively minor projects, which formally met the need for a response to the environmental logic without detracting from the firm's efforts at responding to the market logic.

We labeled the last group of environmental managers as engaged in conditional creation. These managers spoke in terms of "ifs" and "thens" and made it clear they felt the firm's circumstances of financial performance had to improve before the environmental logic could be fully addressed. They saw their ability and willingness to tackle environmental pressures as constrained by whether they were incentivized to do so or whether they could get the right people on board. Rather than seeing themselves as carriers of the environmental logic, these environmental managers perceived their role as curtailed until some or more conditions had been met. This contrasted with the view of those managers who saw the creative challenge in trying to foster environmental engagement within the existing structures and templates of the firm. Instead of addressing the competing logics by capitalizing on opportunities where the market logic stood to benefit from green initiative through, for example, cost savings associated with lower energy costs, these environmental managers postponed addressing the environmental logic until circumstances changed. This may have been the result of the pervasive centrality of the market logic at these firms and the consequent transfer of the market values' assumptions and norms to environmental managers, who, rather than becoming carriers for norms and practices associated with the environmental logic, instead remained carriers of the market imperative (Almandoz, 2014).

Regardless of which form of creation we observed, environmental managers across all three groups had plans for how they would create or utilize organizational structures to address the environmental logic in a setting where the market logic influence was strong. What separated the three groups was the degree to which they were able to successfully implement their plans, and thus meet the twin challenge of the two competing logics that framed their role. Those that relied on strategic or opportunistic creation showed clear signs of successfully embedding environmental management practices, albeit to differing degrees. The conditional creationists on the other hand, had plans for how they would address the firm's environmental agenda, but did not perceive that they had the means to act on it, thus leaving the market logic unchallenged.

Maintenance. Our interviews also revealed a range of activities that the environmental managers engaged with, which focused on audits, risk management, and ensuring on-going regulatory compliance. These were framed as maintenance activities as 
they were largely concerned with production and re-production of practices through the continuation of existing structures (Jarzabkowski et al., 2009). We deemed that environmental managers who worked to ensure compliance with existing regulations but who spoke of no attempts to foresee or account for changes to their environmental institutional environment as engaging in reactive maintenance. By comparison, we labeled those who highlighted attempts and projects to anticipate such changes as engaged in proactive maintenance.

More environmental managers were engaged in proactive maintenance than reactive maintenance. This was largely reflected in proactive maintenance through regular audits. Environmental managers who were attempting to pre-empt and actively manage the on-going competing institutional logics facing them, relied in the main on committee structures, ISO compliance, and formal managerial structures within the firm to frame their engagement with forward looking environmental management. By joining firm level meetings on risks, audits, and feeding into risk management programs, environmental managers used maintenance activities to highlight potential risks from negative environmental impacts on commercial activities, and thus reinforced the salience of the environmental logic for the firm's commercial success. By comparison, environmental managers who reflected a reactive approach did not similarly talk of formal structures as the medium for their work and instead simply noted compliance with laws and regulations and maintenance of status quo. Compared with environmental managers who managed competing logics through creation, these managers, whether proactively or reactively, sought to manage the tension between the market and the environmental logics through compliance, reviews, and environmental scanning, rather than introduce further initiatives beyond those already embedded in existing organizational structures.

Disruption. The final category of institutional work, disruption, was present only in its most tentative form. Disruption has been defined as a precursor to broader change within the organization, and it takes place when the existing institutions and practices no longer meet the interests of the stakeholders (Jarzabkowski et al., 2009). We identified two categories of tentative disruption: one we deemed to be accelerating as it sought to promote environmental management, and another we deemed decelerating as it actively worked to reduce efforts to meet the pressures from the environmental logic. Environmental managers engaged in accelerating disruption if they had either pursued new and innovative approaches to environmental management that extended beyond the usual initiatives of, for example, turning off the light, or if there was clear evidence of aspirations for environmental management projects that could substantively change the firm's approach to their environmental management practices. These environmental managers were in many ways successful in blending the competing institutional logics. The number of environmental managers who fell into this category was small, but reflected an interesting approach to institutional work and institutional logic management. Evidence of accelerating tentative disruption showed that it was possible to address the competing tensions of the market logic and the environmental logic successfully through disruption, without sacrificing one for the other, by creating revenue streams from the environmental logic. "I mean certainly we've reduced waste to landfill by 
5 tons a month. We're actually now earning revenue from our cardboard where we used to pay to get rid of our cardboard" (manufacturing manager, chemicals). In this way, the objectives of the environmental logic were no longer at odds with those of the market logic. Instead, the goals of the two logics were now more aligned, and consequently, the environmental manager no longer faced logics in fierce competition, but rather in symbiosis or blending. By comparison, we deemed evidence of no or decreasing engagement with environmental management as decelerating disruption, as it sought to make environmental management more peripheral (Smith \& Lewis, 2011). Only one of the environmental managers we spoke to did not work on any environmental initiatives: "Not really [have any plans for environmental management], our main, our main concern these days is keeping afloat” (director, retail). This was an unusual response, and as such we felt it important to capture. As institutional work deems disruption to ensue when existing practices no longer fulfill the needs of the firm's stakeholders (Jarzabkowski et al., 2009), the decision to suspend engagement with the environmental logic showed the starkly contrasting outcome that disruption resulted in for some of the firms in our sample: either formerly competing logics showed signs of successful blending, or the market logic crowded out the environmental logic.

\section{Institutional Work and Competing Logics in 2008}

In 2008 environmental managers still negotiated their role in relation to meeting the firm's competing institutional logics of the market and the environment through institutional work. Again we found that creation, maintenance, and disruption were reflected in environmental managers' efforts and initiatives (examples from the data appear in Table 4). Similarly, we found that environmental managers relied on different categories of creation, maintenance, and disruption; some of them were the same as in 2006, whilst others were new for 2008 (see Figure 2).

Creation. A clear theme that emerged from talking to our interviewees, was the sense that they felt great strides had been made in incorporating environmental management into their firms' practices, and that the environmental logic was now more central to the firm than had been the case in 2006. Their engagement with strategic and opportunistic creation had been successful in responding to the environmental logic over time, so we viewed these environmental managers under the label of incremental creation. The interviewees thus believed that they were in a better place to respond to the institutional pressures emerging from the environmental logic, both as environmental managers and at the firm level. Terms like "stronger," "improved," "more important," and "more coordinated" were used to describe how they felt that environmental management had changed. These environmental managers broadly signaled that they felt they were now better able to respond to the environmental logic, even though the market logic was still dominant. One Environment Leader summed it up: "Yes, I think it [environmental management] has gotten stronger. We have better resources now. Certainly, it's more integrated within the business" (engineering). However, it was clear from our data that these changes had not happened over night, and that the changes required to respond to the environmental logic were incremental. Instead, since we last spoke to the 
Table 4: Illustrative Data Supporting the Existence of Institutional Work in 2008

\author{
Conditional creation \\ "If you want to look at environmental integration on a scale, a high priority being seven we will be a one.... \\ The first thing we consider, with absolutely everything is price." \\ "We have lots of plans that have not been financial viable...so, it was not worth making that investment \\ yet, ... it has sort of been put on hold." \\ "We look to the possibility of doing things like windmills on site, and also the possibility of doing a \\ digester and things like this. But all of these have proved to be far too expensive and come with too \\ long a payback period."

\section{Incremental creation} \\ "Well, it is probably more important. It used to be a consideration when you had time, but it is now a \\ day-to-day activity - it is more integrated, yes definitely." \\ "In so far that we implemented systems to ensure that we are recycling properly, that we are avoiding \\ wastes, that we are using the environmentally friendly materials, and washing material, and using energy \\ efficient waste. So, rather than saying that we are going to do and we are now doing it." \\ "It has improved. It has been a slow progress. I think that is the best way to do it."
}

\title{
Reactive maintenance
}

"Since 2006 we obviously had the 14001 approval, there is a requirement to maintain it."

"I think everyone is becoming more aware but I am wondering whether they are sort of paying lip service to avoid doing anything about it."

"I do not think it has changed. Not in this company, I do not think it changed at all since 2006."

"It has not changed. It is not any worse now than it was two years ago."

\section{Tentative accelerating disruption}

"It totally changed. Yes, changed everything. We have got the ISO14001. It has taught me how to complete culture changes if that makes sense and see tangible results. I get what I want and they do not have a choice. It is nice because if they do not do what you want them to do with the system, you issue them with a corrective action and they have to do it then anyway."

"We used to, when we originally spoke, send a supplier self-auditing questionnaire for our suppliers which would tick these boxes: 'if you do this...', 'done that...'. Now, we actually send them an independent organization to audit them."

"We have now basically moved forward and we have actually got the whole [ISO s system up and running. So ... before... I do not think we actually knew what we are doing. I think it would be fair to say, I think we were looking at putting an ISO14000, but a lot of it was about to comply with the standards. What we are now looking at is how we make improvements and a lot of the improvements that we have made on our carbon footprint, on our energy usage, on our wastage."

\section{Tentative deceleration disruption}

"We had to stop recycling, the costs were horrendous."

"It has changed. There is probably less work being done."

environmental managers, they had capitalized on creative work commenced in 2006 and worked consistently to embed practices by "operating somewhat "under the radar'" (Reay \& Hinings, 2009: 645), which over time had caused incremental institutional change.

As in 2006 we also found evidence of conditional creation. However, rather than have plans curtailed by a lack of access to internal resources such as money and people, environmental managers in 2008 found that, though there were initiatives 
and plans that could be implemented, they were more likely to be postponed, pending a resolution to the financial crisis, which began to unfold at the time we conducted our interviews. Whilst initiatives designed to address the firm's impact on the natural environment might still be implemented, this would only happen if they were likely to reinforce the market logic and improve firm financial performance. By emphasizing the market logic when considering their environmental strategy, firms sought to minimize the risk and maximize the potential for financial returns as predicted by Besharov and Smith, who saw changes to the firm's external environment as a catalyst for organizations to "alter their missions in an effort to reduce uncertainty" (2014: 13).

Maintenance. Considering that many environmental managers now saw environmental management as culturally entrenched, and that the incremental creation that had taken place since 2006 had resulted in embedding the environmental logic alongside the market logic, this meant by 2008 fewer were engaged in proactive maintenance. In fact, much of what had been separate audit and future-scanning activities in 2006 were now integral to the ongoing work of the firm, and not just the environmental managers. Instead, some environmental managers spoke of continued reactive maintenance, designed to broadly retain the status quo. Many noted their firms had made no changes since 2006 and one environmental manager, who had expressed a sense of personal engagement and ethical motivation in 2006, was now concerned that the work being done was superficial. He worried about colleagues "paying lip service" only and being engaged in "box-ticking exercises," at the expense of active engagement with the environmental logic.

Disruption. Among the environmental managers who were engaged in disruption, there was increased polarity between those who were ceasing to engage with the environmental logic altogether and those who were embracing it more fully and blending it with the market logic. Those that were decreasing their environmental engagement did so, as it was too costly, at a time when market logic based pressures were increasing in the context of the unfolding financial crisis. Others spoke of the deep cultural shifts that had taken place in their firms, and the complete change they had experienced since 2006. In some instances, the environmental managers now had more power and were able to draw on coercive structures to ensure an environmental strategy was adhered to. Signs of embedded change or major change of this kind were still rare, but there was evidence of change taking place, either through incremental creation or through incidents of positive disruption. Consequently, the competing logics of the environment and the market were developing a growingalbeit often uneasy_co-existence and occasional blending (Reay \& Hinings, 2009).

\section{DISCUSSION}

In this research we asked how does institutional work help environmental managers respond to competing institutional logics? We find that while environmental managers use variations of creation, maintenance, and disruption to manage two competing logics, institutional work did not always lead to successful engagement with both. Whilst strategic, opportunistic, and incremental creation, as well as accelerated disruption, 
were used to bridge or blend competing logics, reactive maintenance, conditional creation, and decelerated disruption were used to segregate the two logics, whereby they co-exist without compromising the centrality of the dominant market logic (Skelcher \& Smith, 2015). Institutional work, therefore, not only resulted in making firms more responsive to their environmental responsibilities as reflected in the environmental logic, but also resulted in some firms reducing their environmental management efforts, or others pursuing a strategy of reinforcing their environmental status quo (Battilana \& D'aunno, 2009).

Environmental managers who successfully blended the environmental and the market logic did so through strategic and opportunistic creation, coupled with accelerated disruption, and proactive maintenance, which over time resulted in incremental change (Reay and Hinings, 2009). Rather than see the environmental logic as marginal to the firm's fortunes, environmental managers instead highlighted the integral role environmental management played, suggesting that the environmental logic and the market logic could peacefully coexist, and even fruitfully blend. As Reay and Hinings (2009) had suggested, pragmatic engagement with firm structures helped environmental managers deliver on both the environmental and the market based logics. This occurred despite the fact that, at least originally, these managers were not specifically tasked with managing both logics simultaneously. As new practices increasingly became accepted by the organization, this led to a revised relationship between the market and the environmental logic (Smets \& Jarzabkowski, 2013). By constructively putting in place new structures and processes that allowed environmental management to become embedded and eventually be seen as the new normal (Winn, Macdonald, \& Zietsma, 2008), and by responding to stakeholders' expectations of greater environmental engagement, environmental managers not only successfully managed the competing logics that faced them, but also redefined their own role. As the values and norms of the environmental logic diffused throughout the company, environmental managers were no longer the sole carriers of the environmental logic, but were instead supported by broader organizational engagement. In some instances, their role had been given even greater status and power, which enabled them to use coercive measures to further strengthen their engagement with both logics (Almandoz, 2014; Rojas, 2009; Zilber, 2011). This finding supports Rojas' (2009) contention, that people wishing to increase or legitimate their roles and power, must work to redefine the institutional parameters that shape their role in the organization, so that the revised order attributes them greater authority.

By comparison, where the market and environmental logic formally co-existed, but where in practice the market logic dominated (Besharov \& Smith, 2014), environmental managers drew on conditional creation, reactive maintenance, and decelerated disruption to pursue what amounted to a strategy of status quo (Battilana \& D'aunno, 2009), or an active disengagement with the environmental agenda. Some cited the unfolding financial crisis as a reason for their environmental inertia, whilst others saw environmental management as too costly, suggesting that adherence to the environmental logic was relatively weaker than their adherence to the market logic (Besharov \& Smith, 2013), or that they felt insufficiently empowered to use institutional work in way that bridged the market and the environmental logic. 
Our findings support the view that it is individuals who shape responses to institutional logics (Lawrence, Leca, \& Zilber, 2013; Lee \& Lounsbury, 2015, Zilber 2002, 2011) by either strengthening or weakening the embeddedness of a peripheral logic within organizational structures through the deployment of practices, initiatives, and activities, both as part of their daily work and by taking a longer-term view. This process depends on the degree to which individual actors feel supported by their firms to adapt to the demands of the peripheral logic and help with diffusing its values, assumptions, rules, and beliefs across their organizations through different forms of institutional work (Dunn \& Jones, 2010; Marquis \& Lounsbury, 2007; Orlitzky, 2011). For some firms this resulted in the intensification of managerial practices designed to integrate and elevate the status of environmental issues in organizational decision making. For others, institutional work amounted to reactive coping mechanisms or even reversals of previous efforts justified on the perceived basis of a dominating market based logic. We thus showed that creation, maintenance, and disruption did not always result in positive outcomes, but could instead also contribute to reinforcing existing patterns of behaviors, norms, and beliefs, which were incompatible with the bridging or blending of competing logics. In the main, however, the nuanced forms of creation and disruption provide individuals with the tools to manage tensions from competing logics by shifting the logics' respective prevalence within the firms.

Bridging or merging competing institutional logics is recognized as an increasing challenge facing organizations, and institutional work offers promise in explaining how firms negotiate the tensions inherent in managing contested logics (Bjerregaard \& Jonasson, 2014; Deroy \& Clegg, 2015; Zilber, 2011), by shifting the debate of institutional logics from the field to the managerial level (Lawrence et al., 2013; Lee \& Lounsbury, 2015; Zilber 2002, 2011). With our focus on the role of environmental managers as the embedded organizational actors and by investigating managerial practices at the individual level, we shed light on the complex and negotiated nature of how individuals cope with the challenges of managing competing logics (Jarzabkowski et al., 2013; Lawrence et al., 2011; Schatzki, 2002).

\section{CONCLUSION}

Firms face a variety of institutional logics and an important question is how individuals at the firm level manage these logics. Environmental managers in particular face tensions over reconciling their firms' commercial fortunes with demands for greater environmental responsiveness. In this article we explored how institutional work helps environmental managers respond to competing institutional logics. Drawing on repeated interviews with $55 \mathrm{UK}$ firms, we find that environmental managers are exposed to competition between a market-based logic and an emerging environmental logic, and note that the latter is becoming more central within many firms over time. Moreover, environmental managers engage through differentiated types of institutional work designed to create, maintain, and disrupt practices used for bridging the tensions between the market and the environmental logics at the firm level. Our findings bring greater nuance to key forms of institutional work, and show that environmental managers play a growing role in diffusing the environmental logic. 


\section{ACKNOWLEDGEMENTS}

We thank the special section editorial team and the three anonymous reviewers for their individual feedback and for creating a highly constructive and developmental review experience. We also thank Russ Vince for his advice and guidance. Finally, we gratefully acknowledge feedback from participants during conferences of the Academy of Management in 2014 and the International Association for Business and Society in 2010.

\section{NOTE}

1. The survey questionnaire is available on request from the authors.

\section{REFERENCES}

Almandoz, J. 2014. Founding teams as carriers of competing logics: When institutional forces predict banks' risk exposure. Administrative Science Quarterly, 59(3): 442-473.

Arragon-Correa, J. A., \& Sharma, S. 2003. A contingent resource-based view of proactive corporate environmental strategy. Academy of Management Review, 28(1): $71-88$.

Asangansi, I. 2012. Understanding HMIS implementation in a developing country Ministry of Health context-An institutional logics perspective. Online Journal of Public Health Informatics, 4(3).

Bansal, P. 2003. From issues to actions: The importance of individual concerns and organizational values in responding to natural environmental issues. Organization Science, 14(5): 510-527.

Bansal, P., \& Roth, K. 2000. Why companies go green: A model of ecological responsiveness. Academy of Management Journal, 43(4): 717-736.

Barley, S. 2008. Coalface institutionalism. In R. Greenwood, C. Oliver, R. Suddaby, \& K. Sahlin (Eds.), The Sage handbook of organizational institutionalism: 419-518. Los Angeles; London; New Delhi: SAGE Publications.

Battilana, J., \& D'uanno, T. 2009. Institutional work and the paradox of embedded agency. In T. B. Lawrence, R. Suddaby, \& B. Leca (Eds.), Institutional work: Actors \& agency in institutional studies of organizations: $31-58$. Cambridge, UK: Cambridge University Press.

Berger, P. L., \& Luckmann, T. 1967. The social construction of reality. New York: Doubleday.

Besharov, M. A., \& Smith, W. K. 2014. Multiple institutional logics in organizations: Explaining their varied nature and implications. Academy of Management Review, 39(3): 364-381.

Bjerregaard, T., \& Jonasson, C. 2014. Managing unstable institutional contradictions: The work of becoming. Organization Studies, 35(10): 1507-1536.

Buysse, K., \& Verbeke, A. 2003. Proactive environmental strategies: A stakeholder management perspective. Strategic Management Journal, 24: 453-470.

Cook, S. D., \& Brown, J. S. 1999. Bridging epistemologies: The generative dance between organizational knowledge and organizational knowing. Organization Science, 10(4): 381-400.

Cordano, M., \& Frieze, I. H. 2000. Pollution reduction preferences of U.S. environmental managers: Applying Ajzen's theory of planned behaviour. Academy of Management Journal, 43(4): 627-641. 
Corley, K. G., \& Gioia, D. A. 2004. Identity ambiguity and change in the wake of a corporate spin-off. Administrative Science Quarterly, 49(2): 173-208.

Cruz, L. B., Delgado, N. A., Leca, B., \& Gond, J. P. 2015. Institutional resilience in extreme operating environments: The role of institutional work. Business \& Society, forthcoming. DOI: 0007650314567438.

Currie, G., Lockett, A., Finn, R., Martin, G., \& Waring, J. 2012. Institutional work to maintain professional power: Recreating the model of medical professionalism. Organization Studies, 33(7): 937-962.

Deroy, X., \& Clegg, S. 2015. Back in the USSR: Introducing recursive contingency into institutional theory. Organization Studies, 36(1): 73-90.

DiMaggio, P. J., \& Powell, W. W. 1983. The Iron Cage revisited: Institutional isomorphism and collective rationality in organizational fields. American Sociological Review, 48(2): 147-160.

Dunn, M. B., \& Jones, C. 2010. Institutional logics and institutional pluralism: The contestation of care and science logics in medical education. Administrative Science Quarterly, 55(1): 114-149.

Egri, C. P., \& Herman, S. 2000. Leadership in the North American environmental sector: Values, leadership styles, and contexts of environmental leaders and their organizations. Academy of Management Journal, 43(4): 571-604.

Esty, D., \& Winston, A. 2009. Green to gold: How smart companies use environmental strategy to innovate, create value, and build competitive advantage. Hoboken, $\mathrm{NJ}$ : John Wiley \& Sons.

Fineman, S. 1997. Constructing the green manager. British Journal of Management, 8(1): 31-39.

Fiss, P. C., \& Zajac, E. J. 2004. The diffusion of ideas over contested terrain: The (non) adoption of a shareholder value orientation among German firms. Administrative Science Quarterly, 49(4): 501-534.

Friedman, F. B. 1992. The changing role of the environmental manager. Business Horizons, 35(2): 25-28.

Gawer, A., \& Phillips, N. 2013. Institutional work as logics shift: The case of Intel's transformation to platform leader. Organization Studies, 34(8): 1035-1071.

Gond, J. P., \& Palazzo, G. 2008. The social construction of the positive link between corporate social and financial performance. Academy of Management Proceedings, 2008(1): 1-6. Anaheim, CA: Academy of Management.

Greenwood, R., \& Suddaby, R. 2006. Institutional entrepreneurship in mature fields: The big five accounting firms. Academy of Management Journal, 49(1): 27-48.

Greenwood, R., Díaz, A. M., Li, S. X., \& Lorente, J. C. 2010. The multiplicity of institutional logics and the heterogeneity of organizational responses. Organization Science, 21(2): 521-539.

Hahn, T., Figge, F., Pinkse, J., \& Preuss, L. 2010. Trade-offs in corporate sustainability: You can’t have your cake and eat it. Business Strategy and the Environment, 19(4): 217-229.

Hine, J. A., \& Preuss, L. 2009. Society is out there, organization is in here: On the perceptions of corporate social responsibility held by different managerial groups. Journal of Business Ethics, 88(2): 381-393.

Jarzabkowski, P., Matthiesen, J. K., \& Van de Ven, A. 2009. Doing which work? A practice approach to institutional pluralism. In T. Lawrence, B. Leca, \& R. Suddaby (Eds.), Institutional work: Actors and agency in institutional studies of organizations: 284-316. Cambridge, UK: Cambridge University Press. 
Jarzabkowski, P., Smets, M., Bednarek, R., Burke, G., \& Spee, P. 2013. Institutional ambidexterity: Leveraging institutional complexity in practice. Research in the Sociology of Organizations, 39(B): 37-61.

Klassen, R. D., \& Whybark, D. C. 1999. The impact of environmental technologies on manufacturing performance. Academy of Management Journal, 42(6): 599-615.

Lawrence, T. B., \& Suddaby, R. 2006. Institutions and institutional work. In S. R. Clegg, C. Hardy, T. B. Lawrence, \& W. R. Nord (Eds.), Handbook of organization studies (2nd ed.): 215-254. London: SAGE Publications.

Lawrence, T. B., Suddaby, R., \& Leca, B. 2011. Institutional work: Refocusing institutional studies of organization. Journal of Management Inquiry, 20(1): 52-58.

Lawrence, T. B., Malhotra, N., \& Morris, T. 2012. Episodic and systemic power in the transformation of professional service firms. Journal of Management Studies, 49(1): $102-143$.

Lawrence, T. B., Leca, B., \& Zilber, T. B. 2013. Institutional work: Current research, new directions and overlooked issues. Organization Studies, 34(8): 1023-1033.

Lee, M. D., \& Lounsbury, M. 2015. Filtering institutional logics: Community logic variation and differential responses to the institutional complexity of toxic waste. Organization Science, 26(3): 847-866.

Lee, S. Y., \& Rhee, S. K. 2007. The change in corporate environmental strategies: A longitudinal empirical study. Management Decision, 45(2): 196-216.

Lockett, A., Wright, M., \& Wild, A. 2015. The institutionalization of third stream activities in UK higher education: The role of discourse and metrics. British Journal of Management, 26(1): 78-92.

Lounsbury, M. 2002. Institutional transformation and status mobility: The professionalization of the field of finance. Academy of Management Journal, 45(1): 255-266.

- 2007. A tale of two cities: Competing logics and practice variation in the professionalizing of mutual funds. Academy of Management Journal, 50(2): 289-307.

Maguire, S., Hardy, C., \& Lawrence, T. B. 2004. Institutional entrepreneurship in emerging fields: HIV/AIDS treatment advocacy in Canada. Academy of Management Journal, 47(5): 657-679.

Mantere, S., \& Ketokivi, M. 2013. Reasoning in organization science. Academy of Management Review, 38(1): 70-89.

Marquis, C., \& Lounsbury, M. 2007. Vive la résistance: Competing logics and the consolidation of US community banking. Academy of Management Journal, 50(4): 799-820.

Myers, M. 2013. Qualitative research in business and management. London: Sage.

Orlitzky, M. 2011. Institutional logics in the study of organizations: The social construction of the relationship between corporate social and financial performance. Business Ethics Quarterly, 21(03): 409-444.

Pache,A.C., \& Santos, F. 2010. When worlds collide: The internal dynamics of organizational responses to conflicting institutional demands. Academy of Management Review, 35(3): 455-476.

Patten, D. M. 2002. The relation between environmental performance and environmental disclosure: A research note. Accounting, Organizations and Society, 27(8): 763-773.

Prasad, P., \& Elmes, M. 2005. In the name of the practical: Unearthing the hegemony of pragmatics in the discourse of environmental management. Journal of Management Studies, 42(4): 845-867. 
Ramirez, C. 2013. 'We are being pilloried for something, we did not even know we had done wrong!' Quality control and orders of worth in the British audit profession. Journal of Management Studies, 50(5): 845-869.

Ramus, C. A., \& Steger, U. 2000. The roles of supervisory support behaviours and environmental policy in employee "ecoinitiatives" at leading-edge European companies. Academy of Management Journal, 43(4): 605-626.

Reay, T., \& Hinings, C. R. 2009. Managing the rivalry of competing institutional logics. Organization Studies, 30(6): 629-652.

Reay, T., \& Jones, C. 2015. Qualitatively capturing institutional logics. Strategic Organization, forthcoming. DOI: 1476127015589981.

Rojas, F. 2010. Power through institutional work: Acquiring academic authority in the 1968 third world strike. Academy of Management Journal, 53(6): 1263-1280.

Rothenberg, S. 2007. Environmental managers as institutional entrepreneurs: The influence of institutional and technical pressures on waste management. Journal of Business Research, 60(7): 749-757.

Roulet, T. J. 2015. 'What good is wall street?' Institutional contradiction and the diffusion of the stigma over the finance industry. Journal of Business Ethics, 130(2): 389-402.

Rousseau, H. E., Berrone, P., \& Walls, J. 2014. Let's talk: Examining dialogue among firms and outside actors on social and environmental issues. Academy of Management Proceedings. Philadelphia, PA: Academy of Management.

Schatzki, T. 2002. The site of the social: A philosophical exploration of the constitution of social life and change. State College, PA: Pennsylvania State University Press.

Schneider, A. 2015. Reflexivity in sustainability accounting and management: Transcending the economic focus of corporate sustainability. Journal of Business Ethics, 127(3): $525-537$.

Scott, W. R. 2000. Institutional change and healthcare organizations: From professional dominance to managed care. Chicago: University of Chicago Press.

Sharma, S. 2000. Managerial interpretations and organizational context as predictors of corporate choice of environmental strategy. Academy of Management Journal, 43(4): 681-697.

Sharma, S., \& Vredenburg, H. 1998. Proactive corporate environmental strategy and the development of competitively valuable organizational capabilities. Strategic Management Journal, 19(8): 729-753.

Sharma, S., Pablo, A. L., \& Vredenburg, H. 1999. Corporate environmental responsiveness strategies the importance of issue interpretation and organizational context. The Journal of Applied Behavioral Science, 35(1): 87-108.

Slager, R., Gond, J. P., \& Moon, J. 2012. Standardization as institutional work: The regulatory power of a responsible investment standard. Organization Studies, 33(5-6): 763-790.

Smets, M., \& Jarzabkowski, P. 2013. Reconstructing institutional complexity in practice: A relational model of institutional work and complexity. Human Relations, 66(10): 1279-1309.

Smith, W. K., \& Lewis, M. W. 2011. Toward a theory of paradox: A dynamic equilibrium model of organizing. Academy of Management Review, 36(2): 381-403.

Styhre, A. 2014. Gender equality as institutional work: The case of the Church of Sweden. Gender, Work and Organization, 21(2): 105-120.

Suddaby, R., \& Viale, T. 2011. Professionals and field-level change: Institutional work and the professional project. Current Sociology, 59(4): 423-442. 
Thornton, P. H., \& Ocasio, W. 1999. Institutional logics and the historical contingency of power in organizations: Executive succession in the higher education publishing industry, 1958-1990. American Journal of Sociology, 105(3): 801-843.

- 2008. Institutional logics. In R. Greenwood, C. Oliver, R. Suddaby, \& K. Sahlin (Eds.), The Sage handbook of organizational institutionalism: 99-128. London: Sage.

Thornton, P. H. 2002. The rise of the corporation in a craft industry: Conflict and conformity in institutional logics. Academy of Management Journal, 45(1): 81-101.

Tilcsik, A. 2010. From ritual to reality: Demography, ideology, and decoupling in a postcommunist government agency. Academy of Management Journal, 53(6): 1474-1498.

Van Gestel, N., \& Hillebrand, B. 2011. Explaining stability and change: The rise and fall of logics in pluralistic fields. Organization Studies, 32(2): 231-252.

Van Maanen, J., Sørensen, J. B., \& Mitchell, T. R. 2007. The interplay between theory and method. Academy of Management Review, 32(4): 1145-1154.

Veal, G., \& Mouzas, S. 2012. Market-based responses to climate change: CO2 market design versus operation. Organization Studies, 33(11): 1589-1616.

Welford, R., \& Gouldson, A. 1993. Environmental management and business strategy. London: Pitman Publishing Limited.

Willmott, H. 2011. Institutional work for what? Problems and prospects of institutional theory. Journal of Management Inquiry, 20(1): 67-72.

Winn, M. I., MacDonald, P., \& Zietsma, C. 2008. Managing industry reputation: The dynamic tension between collective and competitive reputation management strategies. Corporate Reputation Review, 11(1): 35-55.

Yu, K.-H. Y. 2013. Institutionalization in the context of institutional pluralism: Politics as a generative process. Organization Studies, 34: 105-131.

Zietsma, C., \& Lawrence, T. B. 2010. Institutional work in the transformation of an organizational field: The interplay of boundary work and practice work. Administrative Science Quarterly, 55(2): 189-221.

Zilber, T. B. 2002. Institutionalization as an interplay between actions, meanings, and actors: The case of a rape crisis center in Israel. Academy of Management Journal, 45(1): 234-254.

. 2011. Institutional multiplicity in practice: A tale of two high-tech conferences in Israel. Organization Science, 22(6): 1539-1559. 


\section{APPENDIX}

\section{RESPONDENTS' JOB TITLES}

Administrative Director

Business Manager

Chairman

Chairwoman \& Chief Executive Officer

Commercial Manager

Corporate Sustainable Development Manager

Director

Director Health \& Safety

Director of Environment \& Sustainability

Environment Coordinator

Environment Leader

Environment Officer

Environment, Health \& Safety Manager

Environment, Safety \& Security Manager

Environmental Control Manager

Environmental Manager (x6)

Environmental Risk Manager

European Group Quality Assurance Manager

Farmer \& Joint Owner

Group Business Development Director

Group Corporate Social Responsibility Manager

Group Environmental Advisor

Group Health \& Safety Manager
Group Head of Environment

Group Health, Safety \& Environment Manager (x2)

Health, Safety \& Environment Manager (x3)

Health, Safety \& Environmental Advisor

Manager Environmental Affairs

Managing Director

Manufacturing Manager

Operations \& Facilities Manager

Operations \& Supply Assistant

Operations Manager

Operations, Utilities Director

Principal Environment Officer

Quality, Safety \& Environment Coordinator

Quality \& Environmental Manager

Quality Manager (x3)

Regional Sales Manager

Safety Engineer

Senior Manager

Safety, Health, Environment \& Quality Manager

Social Responsibility Advisor

Sustainability Controller

Technical Director 